\title{
Kent ve Salgın: Yeni Yaklaşımlar ve Kamu Sağlığı Üzerine Bir Değerlendirme
}

\author{
Ece Varol 1 \\ ORCID: 0000-0002-2502-6448
}

\author{
Ahmet Melih Öksüz ${ }^{2}$ \\ ORCID: 0000-0002-9312-7312
}

\section{Öz}

Insanların diğer canlılar ile ortak yaşam alanların kullanma biçimleri, kentlerde ve konut mekanlarındaki sağlıksız koşullar, yaşanan iklim değişiklikleri gibi pek çok nedenden ötürü çağlar boyunca insanlık tarihinde pek çok salgın hastalıkla mücadele edilmiştir. Kentler üzerinde sarsıcı etkiler bırakan salgınlar sonrası mevcut yapı stoklarının iyileştirilmeye ve sağlıklı kentler yaratabilmek adına yeni yapıların üretilmeye başlandığı görülmektedir. Bu çalışmanın oluşturulmasının temel amaci; salgının kentler üzerindeki etkileri ve yarattığ değişimleri vurgulayarak, özellikle günümüzde yaşanılan Covid-19 pandemi süreci ile planlama ve tasarım yaklaşımlarının yeniden gözden geçirilmesine ışık tutulmasının sağlanmasıdır. Salgınların önemli bir etki alanlarının kentler olduğu göz önüne alındığında daha esnek ve sürdürülebilir mekanlarn yaratılması gerekliliği söz konusu olmaktadır. Çoğunlukla 'Yeni normal' diye isimlendirilen bu süreç ile dünyada süregelen yaşamsal devamlılı̆̆ın boyut değiştireceği iddia edilmektedir. Bu sürece en etkin biçimde adapte olmak ve güncel kentsel yaklaşımların bu 'normal'e ne kadar cevap verebildiği tartışma konusu olmaktadır. Çalışma, konuya ilişkin yapılan çeşitli uygulamaların literatürle ilişkili olarak bir değerlendirmesini sunmaktadır. Yaşanan salgınların özellikle kentlerde oluşturduğu mekânsal kullanım değişikliklerinin incelenmesi ve akıllı kent gibi söylemlerin uygulama alanlarının salgınlar özelinde incelenmesi çalışmanın sonuçlarını oluşturmaktadır.

Anahtar Kelimeler: Kent, salgın hastalıklar, covid-19, kamu sağhlğg, akıllı kentler.

\footnotetext{
${ }^{1}$ Arş. Gör., Karadeniz Teknik Üniversitesi, E-mail: eceseyhanvarol@gmail.com

2 Prof. Dr., Karadeniz Teknik Üniversitesi, E-mail: m_oksuz@ktu.edu.tr

idealkent @ C Kent Araştırmaları Dergisi (Journal of Urban Studies) 


\title{
The City and the Pandemic: An Evaluation on New Approaches and Public Health
}

\author{
Ece Varol ${ }^{3}$ \\ ORCID: 0000-0002-2502-6448
}

\author{
Ahmet Melih Öksüz ${ }^{4}$ \\ ORCID: 0000-0002-9312-7312
}

\begin{abstract}
Many pandemic diseases have been fought over the ages due to many reasons such as the way people use their common living spaces with other living things, unhealthy conditions in cities and dwellings and climate changes. After the pandemics, the existing building stocks started to be improved and new buildings started to be produced. The main purpose of this study is; emphasizing the effects of the pandemic on cities and the changes it has created, it is to shed light on the revision of planning and design approaches, especially with the covid-19 pandemic process experienced today. Therefore, with the pandemics, the planning of cities should be more flexible and sustainable. It is thought that most habits will change with this process, which is called the 'new normal'. How much current urban approaches can respond to this 'normal' is a matter of debate. The study presents an evaluation of various practices on the subject in relation to the literature. The results of the study are to examine the spatial use changes caused by the pandemics, especially in cities, and to examine the application areas of discourses such as smart cities.
\end{abstract}

Keywords: City, pandemics, covid-19, public health, smart cities.

\footnotetext{
${ }^{3}$ R. A., Karadeniz Technical University, E-mail: eceseyhanvarol@gmail.com

${ }^{4}$ Prof. Dr., Karadeniz Technical University, E-mail: m_oksuz@ktu.edu.tr
} 


\section{Giriş}

Tarihsel süreçte yaşanan çok sayıda salgın hastalık ile halk sağlı̆̆ kavramı günümüzde yaşanan Covid-19 salgını nedeniyle tekrar gündeme gelmektedir. Kent planlaması ve halk sağlığı disiplinlerinin ortak amaçları bulunmaktadır. Kent planlaması 'kamu yararının' koruyucusu olarak tanımlanırken, halk sağlığı; hastalığın belirlenmesi, kontrolü ve önlenmesi ile ilgilidir. Kentlerin akciğerleri şeklinde fizyolojik bir metaforla atıf yapılan park ve açık alanların varlığı, halk sağlığı ve kentlerin yakın bağını açıkça ifade etmektedir. İçinde yaşayanlarının beden sağlığı için fiziksel aktivite düzeylerine katkı sunan kentsel açık alanlar (Çetintahra ve Çubukçu, 2015) ve sosyo-kültürel yaşantıyı destekleyen kentsel fiziksel çevre kurgusu içindeki kentsel dış mekanların (Erdönmez ve Akı, 2005) tasarım ve planlanması kent kullanıcılarının yaşamlarını etkilemektedir. Kent planlamasının odak noktası, sağlığı geliştirecek ve ilk etapta hastalıkların ortaya çıkmasını önleyecek şekilde şehrin fiziksel düzeninin oluşturulmasıdır. Tarihsel süreçte ortaya çıkan kent planlama ve tasarım teorileri, kavramları, düzenlemeleri ve uygulamaları; salgın hastalıklar, hızlı sanayileşmeyle oluşan kirlilik, yoğun kentleşme, kentlerdeki yeşil alan kayıpları gibi yaşanan halk sağlı̆̆ı merkezli krizlere yanıt olarak ortaya çıkmıştır (Banai, 2020).

Tarihsel süreç içinde 1800'lerin sonlarında hem planlama hem de kamu sağlığı uzmanlıklarının, kentlerdeki hastalıklarla yakından ilgilendiği görülmektedir. Kentler, yoğun yapılaşma içerisinde, sağlığa zararlı bir büyüme göstererek hastalıklara zemin hazırlamakta ve sosyal bozukluklara yatkın olarak görülmekteydi. Bulaşıcı hastalıkların salgınları oldukça yaygın olmakla birlikte belli bir çevrede oluşan bir hastalık tüm kente yayılma tehlikesi altındaydı. Dolayısıyla bu nedenle kentlerin temizliği, suların iyileştirilmesi, kentlerin popülasyonları açısından daha düşük yoğunluklu yerleşimlerin gelişiminin teşvik edilip, nüfusun yoğunluğunu merkezden uzaklaştırmaya yönelik birtakım konulara odaklanılmıştır (Carmona vd., 2010). Salgınlar, dünya tarihinde yaşam ve yönetim değişikliklerine yol açan ve küresel etkileri olan sağlık olaylarıdır. Tarihte yaşanmış büyük çaptaki salgınlar, beslenmeden mimariye, hatta imparatorlukların yıkımına kadar pek çok konuda sosyal, ekonomik ve siyasal olarak yeni gelişmeleri beraberinde getirmiştir (Türkiye Bilimler Akademisi, 2020).

Günümüzde yaşanmakta olan Covid-19 krizinin ilk günlerinden beri bilim camiası virüsün yayılmasını sağlayan mekanizmalar, çevresel ve sosyo- 
ekonomik etkileri, gerekli müdahale ve uyum planları ve politikaları gibi çeşitli konulara ışık tutmaya çalışmaktadır. Kentlerdeki yüksek nüfus yoğunluğu ve ekonomik faaliyetler genellikle Covid-19 enfeksiyonunun etkin noktalarını oluşturmaktadır. Buna göre, birçok araştırmacı Covid-19'un kentler üzerindeki etkilerini anlamak adına kentsel alanlardaki salgının dinamiklerini araştırmayı sürdürmektedir (Sharifi ve Khavarian-Garmsir, 2020).

$\mathrm{Bu}$ çalışma geçmişten günümüze dünyada yaşanmış salgınların kısa bir tarihçesi ve kentlerde yarattığı değişimlerden bahsettikten sonra günümüzde yaşanan Covid-19 salgını ile ilişkili olarak akıllı kent kavramının salgın döneminde, salgının kontrolü ve yönetimi açısından ne tür katkılar sağladığ1 ve gelecekte bu tür sorunların çözümünde kent planlama açısından ne tür potansiyeller taşıyabileceği konularının üzerinde durmayı amaçlamıştır. Kentlerin tarihsel süreç içinde geçirdiği değişimler ile olgunlaşarak büyüyen bir canlı organizma olduğu düşünüldügünnde 'akıllı kent' gibi söylemlerin kentteki mevcut işleyiş ile nasıl bir uyum yakalayacağı ve yaşanan bu pandemi sürecine ne kadar çözüm bulacağı da başlıca bir tartışma konusudur. Sonuç olarak "Halk sağlığı ayn zamanda toplumsal mekan ve kamusal planlama sorunsalıdır" (TMMOB Şehir Plancıları Odası, 2020) bakış açısıyla değerlendirildiğinde pandemi sonrasında kentsel sorunları azaltmak ve akıllı kentlerin gelecekte meydana gelebilecek salgınlar karşısında kamu sağlı̆̆ üzerine temellendirdiği yeni düzenlemeler yapması gerekliliğinin önem kazanacağı düşünülmektedir.

\section{Tarihsel Süreçte Önemli Pandemiler ve Etkileri}

Oxford İngilizce Sözlüğü pandemiyi; neredeyse bir alanın tamamını veya bir grup insan, hayvan ve bitkinin neredeyse tümünü etkileyen bir hastalık (disease) olarak tanımlamaktadır (Oxford İngilizce Sözlüğü, 2020). Pandemi (eski Yunanca' dan pan: tüm + demos: insanlar), dünyada birden çok ülke veya kıtada, çok geniş alanlara yayılıp etkisini gösteren salgın hastalıklara verilen genel bir isimdir. Dünya Sağlık Örgütü'ne (DSÖ) göre bir hastalığın pandemi olabilmesi için bir virüs veya mutasyona uğramış bir etken olmalı, insanlara kolayca geçebilmeli ve sürekli bir şekilde bulaşıcı olmalı şeklinde üç kriter aranmaktadır. Pandeminin ilanı ancak bu kriterler gerçekleştiğinde DSÖ tarafından ilan edilmektedir. Pandeminin ilanı, tüm ülkeler için tehdit unsuru oluşturan bu hastalık etkenin kolayca yayılıyor olduğunu açıkça ifade etmektedir (Türkiye Bilimler Akademisi, 2020).

İnsanlık tarihinde çağlar boyunca pek çok salgın hastalıkla mücadele edilmiştir. Dünya tarihinde bilinen en eski salgın hastalık kanıtlarına M.Ö. 5000 
yıllarda Kuzeydoğu Çin'in Mangha ve Miaozigou arkeolojik yerleşim alanlarındaki toplu mezarlardaki iskeletlerde rastlanılmıştır (Yılmaz, 2021). Yaşanan büyük çaplı salgınlar arasında 1720'deki Marsilya Salgını, 1817 ve 1923 yılları arasında yaşanan kolera salgını, 1817-1823 yılları arasında Hindistan'daki Ganj Nehri deltasında yayılan kolera salgını, 1918-1919 yılları arasinda İspanyol gribi, 1957, 1958 ve 1968'de Asya gribi, 1968'de Hong Kong gribi, 2009 (H1N1 gribi) yılı domuz gribi ve 2019'un sonunda Çin'in Hubei eyaletine bağlı Wuhan kentinde Covid-19 olarak adlandırılan salgını içermektedir (Abusaada ve Elshater, 2020). Bugüne kadar yaşanmış salgın hastalıklardan tarihsel süreçte en ciddi sonuçlar ortaya çıkaran salgınların veba, kolera, tifüs, çiçek, ebola ve grip olduğu bilinmektedir (Türkiye Bilimler Akademisi, 2020).

\section{Veba (Kara Ölüm)}

Kara Ölüm" olarak bilinen vebanın tarihte ilk olarak İsa'dan 320 yil kadar önce Filistin'de görüldüğ̈̈ tahmin edilmektedir (Arda, 1997; Özden ve Özmat, 2004). Çin ve Orta Asya'da başlayan ve 13.yüzyılda Avrupa nüfusunun üçte birinin ölümüne neden olan bu hastalığının, pirelerin insanları ısırması yoluyla veya enfekte olan insanlar arası bulaşı vasıtasıyla gerçekleştiği bilinmektedir (Türkiye Bilimler Akademisi, 2020).

\section{Kolera}

Vibrio cholerae bakterisinin neden olduğu bağırsak enfeksiyonuna bağlı yaşanan bu salgın, 1817' de Japonya'da, 1826'da Moskova'da, 1831'de Berlin'de, Paris'te ve Londra'da, 1892 yılında Hamburg'da ve Kanada'da binlerce kişinin ölümüne neden olmuştur. Ülkemizdeki en büyük kolera salgını 1912-1913 Balkan Savaşları sırasında görülmüştür (Aslan, 2020). Özellikle kolera salgınının en büyügü olarak nitelendirilebilecek olan üçüncü yayılımında salgın sırasında doktorların gözlemleriyle koleranın, içme sularının kirli olmasından kaynaklandığı anlaşılmışır. Bu bilgiden sonra suların temizlenmesi ve kaynatılması yaygın olarak yapılmaya başlanmıştır (Tekeli, 2020).

\section{Ispanyol Gribi}

1918-1920 yılları arasında 18 ay içinde 100 milyona yakın insanın (dünya nüfusunun \%15'inin) ölümüne neden olan tarihte yaşanmış bilinen en büyük salgındır. İspanyol gribi özellikle yaşlı ve çocuklardan çok, sağlıklı genç erişkinleri ölümcül olarak etkilemiştir (Aslan, 2020). 1918'de I. Dünya Savaşı s1rasındaki askeri kampların sürekli yer değiştirmesi ile tarihteki yaşanan grip 
salgınları içindeki en büyüğü olan bu salgın, bir pandemi haline gelmiştir (Parildar, 2020).

\section{Çiçek Hastalığı}

"Büyük Kıyım ve Bir Halk Sağlığı Başarısı" olarak ifade edilen ve tarihte en geniş yayılıma sahip olmasıyla birlikte çok sayıda ölüme (300-500 milyon kişi) neden olan bir salgındır. Bu salgın pek çok kültürü yok ederek, kimi uygarlıkların sonunu getirmiştir (Parıldar, 2020). Poxvirüs ailesinden olan çiçek virüsü, hastanın eşyalarıyla, hastaya temas ile, sineklerle ve inhalasyonla bulaşmaktadır. Ayrıca tarihteki ilk aşı çiçek aşısıdır (Türkiye Bilimler Akademisi, 2020).

\section{Tifüs ve Ebola}

İkinci Dünya Savaşında İstanbul'da ciddi şekilde yaşanan Tifüs salgınının, bit ve pirelerin vektörlük ettiği bulaşıc bir enfeksiyon hastalığı olduğu bilinmektedir. Ebola virüsü ise insanlar ve insan dışı primatlarda çeşitli komplikasyonlara neden olmaktadır (Türkiye Bilimler Akademisi, 2020).

\section{Salgınların Toplumsal Hayata ve Kentsel Mekân Kullanımına Etkileri}

Tarihsel süreç içerisinde ortaya çıkan salgın hastalıklar, ortaya çıktıkları yerleşmelerde toplumsal yaşam biçimini derinden etkileyerek değiştirmişlerdir. Toprağın sürekli sürülmesi, yeni tarım alanları arayışı, ormanların yok edilmesi gibi sebeplerden ötürü insanlar, hayvanların yaşam alanlarına giderek yakınlaşmaya başlamıştır. Bu durumda insanla ortak mekanları kullanmaya başlayan fare, sıçan, kene ve pire gibi pek çok tür, yanlarında salgın hastalıklarla birlikte gelmiştir. İnsanların hayvanlardan gelen hastalıklarla mücadelesi, yerleşik yaşama geçişlerde temiz su bulma güçlüğü, ulaşım alternatifleri geliştikçe farklı bölgelerde yaşayanların iletişimlerinin kolaylaşması ve kentlerin kurulması ile çok sayıda insanın beraber yaşaması sonucunda pek çok büyük salgınla karşı karşıya kalındığı görülmektedir. Yaşanan salgınlar sonucu yüz binlerce insan hayatını kaybedip, toplu ölümler yaygınlaşmıştır. Azalan nüfus ile kentlerin bazıları hayalet kasabalara dönüşmüştür (Özden ve Özmat, 2014). “Gelmiş Geçmiş En Büyük Katil: 1918 'İspanyol’ Gribi” adlı kitapta da söylenen, Güneydoğu Çin ya da daha geniş bir bölge olan Güneydoğu Asya gibi çok kalabalık insan ve hayvan nüfusunun iç içe yaşadığı toplumlarda epidemi ve pandemilerin patlak verebileceği yönündedir (Temel ve Ertin, 2020). Dolayısıyla yoğun nüfusa sahip bölgelerde, hayvanlarla kontrolsüzce yaşanan yakın temasların hastalıklara elverişli sağlıksız koşullar yarattığ1 söylenebilir. 
Yaşanan salgınların toplumsal hayata ilişkin bazı işleyişleri değiştirdiği görülmektedir. Bu salgınların pek çoğunda ekonomik gelirin düşük olduğu kişilerin, hastalıklardan daha çabuk etkilendiği görülmektedir. Bu durumda bireylerin yaşadıkları fiziksel şartları düzeltme noktasında yetersiz kalmaları, hastalığın kontrol altına alınmasını da güçleştirmektedir. Ancak her ne kadar genel kanı ve yaklaşım bu olmakla birlikte, geçmişte soyluların, zenginlerin, din adamlarının ve üst sınıfların da halk kitleleri gibi bu salgınlardan etkilendiği bilinmektedir. Salgınlarda bireylerin ruhsal durumlarının sosyal davranış biçimlerine etki ederek dolayısıyla toplumsal yapıyı da yakından etkilediği görülmektedir.

Salgınların, geçmişte toplu insan kayıpları ile yarattığı demografik sonuçlar dışında kentsel mekanların kullanımları üzerinde de pek çok değişim yarattı̆̆ görülmektedir. Kentlerde temizlik ve altyapı hizmetlerinin önemi kavranmış, bu konuda çalışmalar hızlandırılmıştır. Yerel yetkililer yayınladıkları genelgelerle salgını kontrol altına almaya çalışmışlardır. Kentteki pazar alanları akşam saatlerinde temizlenmiş ve belediye tarafından işletilen hamam yapıları kullanıma açılmıştır. (Atabek, 1977; Özden ve Özmat, 2014). 19.yy İngiltere'sinde uzun süreli çalışma saatleri olan işçilerin malzeme olarak düşük kaliteli tuğla ile çevrili olarak kiralanan, tek odalı, penceresi olmayan, gün ışığı almayan bodrum tipi yerlerde oldukça kötü yaşam şartlarında yaşıyor olmaları, evlerden sokaklara taşan kir ve kokuya bir de yeterli temiz su bulamama sorunu ekleninca salgın hastalıklar kaçınılmaz olmakta idi (Karabaş, 2008). 19.yüzyılda dünyanın en büyük kenti haline gelen Londra'da, işçi sınıfın yaşadığı rutubetli ve çok sıkışık sağlıksız konutlar nedeni ile İngiltere' deki ilk sağlık reform yasası 1832 tarihinde kolera salgını sonucu çlkartılmıştır. 1847 yılında ise ilk ‘Public Health Act' (Halk Sağlı̆̆ı Yasası) çıkartılmıştır. Çıkarılan bu yasada sağlık şartlarının iyileştirilmesi için içme sularının sağlanması, kanalizasyon ve yağmur suyu kanallarının inşası, yolların kaplanması, kent yollarının temizlenmesi, katı atıkların toplanması, mezbahalar kurulması, halk bahçeleri yapılması gibi bir takım öneriler sunulmuştur. Sanayi devriminin yarattığı sağlıksız yaşam koşulları ve yaşanan kolera salgınları, modern şehirciliğin sağlık odaklı olarak kurulmasına zemin hazırlamıştır (Tekeli, 2020). Bununla beraber kent planlama ve tasarım literatüründe bilinen Bahçe Şehir, Güzel Şehir, Le Corbusier'in La Villette kurgusu gibi ütopyalar çoğunlukla sağlık ve kent ile yapılı çevre kurgusu üzerinden tanımlanmıştır. Bu kurgular oluşturulurken, yapı yoğunluğunun belirli seviyede tutulması, geniş yeşil ve kamusal alanların tasarımı ile kentsel hizmetlere erişim 
kolaylığı, kamu yararının dikkate alınması, sosyal eşitlik gibi tasarım ve şehircilik ilkeleri ön plana çıkarılmıştır (Özüduru, 2020). Özden ve Özmat (2020) veba salgını sonucu Avrupa'nın salgından kurtulması ve salgının tekrar etmemesinin önemli nedenleri için; mevcut yapı stoklarının iyileştirilmesi, sağlıklı yeni yapı stokları üretilmiş olması, mimariyi ve yapılarda kullanılan teknik ve malzemelerin önemli biçimde değiştirilmesi şeklinde özetlemiştir.

Yaşanan salgınların kent ölçeğinde yarattı̆̆ı değişimlerin yanı sıra kentlerin çepere yayılması ile toplumsal yaşamı da etkilediği söylenebilir. Kolera, tüberküloz ve sarılık gibi hastalıklar nedeniyle kentsel altyapı düzenlemelerinin dışında, sokakların sağlıklaştııılması, bina ve yapıların işlevlerine göre ayrıştırılması, varlıklı kesimin kentsel alanların çeperlerine kaçışı ile çeşitli kentsel büyüme modellerine ilişkin değişimler yaşanmıştır (Özüduru, 2020). Özellikle 19.yy'da artan nüfusun halk sağlığını tehdit etmesi, kentsel büyüme planlamasına yönelik çalışmaları başlatmıştır. Kent merkezlerinin etrafına uydu kentler açılmış, kapalı siteler yapılarak artan nüfusun çeperlere dağıtılması amaçlanmıştır (Yılmazsoy vd., 2021).

\section{Covid-19 Pandemisi, Yayılımı ve Etkileri}

21.yüzyılda dünyanın gündeminde yer tutan bir diğer virüs ailesi, koronavirüslerdir. Bunların ilki olan SARS, 2003 yılında Asya'da, ikincisi Mers--CoV 2012 yılında Suudi Arabistan'da saptanmıştır. İki virüse karşı da aşı ya da antiviral ilaç geliştirilememiştir. 2020 yılına girerken, Covid-19, CoV virüsü yarasa ve bir tür karıncayiyen pandolin üstünden insanda tutunarak, hastalık yaratmaya başlamıştır. Covid-19 hastalığının geçmişteki salgınlardan önemli bir farkı hastalanan kişilerin \%80'inin teşhis edilmeden toplum içinde hayatlarına devam ediyor olmasıdır. Geçmişte salgınlara karşı yapılan karantina önlemleri ile hastalığı teşhis edilen kişilerin saptanarak, toplumun geri kalanından izole edilmesi sağlanmaktaydı. Ancak bu hastalığı herhangi bir semptom geçirmeden yaşayan kişiler (asemptomik hasta) nedeniyle hastalık toplumda dolaşarak çok hızlı şekilde yayılım göstermektedir. Dolayısıyla bu salgındaki yayılımın denetim altına alınabilmesi için toplumun tümüne ilişkin izolasyon/karantina tedbirleri alınması gerekmektedir (Tekeli, 2020). Çin'in Wuhan kentinde 2019'un son aylarında meydana geldiği için Covid-19 olarak isimlendirilen bu salgın, 11 Mart 2019'da Dünya Sağlık Örgütü (DSÖ) tarafından pandemi (küresel salgın) olarak tanımlanmıştır (Bayhan, 2020).

Salgının insanlar üzerindeki etki derecesi virüsün enfektivitesine, toplumun bağışıklık düzeyine, bireylerin yaşam alışkanlıkları ve sosyo ekonomik 
durumlarına, bireylerin ülkeler ve şehirlerarası mesafe aşım kolaylıklarına, çalışma hayatındaki risk faktörlerine, pandeminin yayılım gösterdiği ülkedeki sağlık hizmetlerinin kalitesine ve salgın etkeninin iklime bağlı olarak olumlu veya olumsuz bir tavır değiştirme kabiliyetine göre yayılımı değişiklik göstermektedir (Türkiye Bilimler Akademisi, 2020). Salgının kontrol edilme sürecinde özellikle kentlerin yerel düzeyde merkezi karar alma biçimleri, sürece aktif katılım ve uygulamalar pandemilerle mücadelede başarılı olmak için önemli mekanizmalardır. Sağlıklı kentsel yapılı çevre oluşturmak için yeterli yer, güvenlik ve sağlıkla ilgili konuların entegre bir şekilde sağlanması önerilmektedir. Buna ek olarak, güvenli su, yeşil çevre, iklim değişikliğine yönelik adaptasyonlara dayalı stratejiler, kapsamlı topluluk planlaması, binaların içindeki yoğunluğun azaltılması vb. gibi uygulamaların gelecekteki kentsel yapılı çevre tasarımı için bir çözüm olabileceği görülmektedir (Ahsan, 2020). Salgının etki alanı ve yaratacağı değişimler düşünüldüğünde salgin meydana geldiği andan itibaren gerekli tedbirlerin sistematik bir biçimde alınması ve halkın bu bilinçle hareket etmesi sağlanmalıdır. Aksi durumda salgın hızla yayılım göstermeye devam ederken, halk sağlığı açısından kentlerde olumsuz senaryolar yaşanmaya başlanması kaçınılmaz olmaktadir.

\section{Covid-19 ve Kentsel Mekana İlişkin Değişimler}

Pandemi sürecince ülkeler ve kentler açısından doğanın ve tarım alanların korunmasının önemi ortaya çıkmıştır. Böylece ülkesel düzeyde verimli toprakların korunması ve gıda sıkıntısı yaşanmaması için tarımsal üretim, hayvancılık gibi faaliyetlere ağırlık verilmiş ve devlet desteğinin artırılması yaşanabilecek riskleri azaltma açısından önem taşımıştır. Atık yönetimi, temiz su ve enerji tasarrufu konuları da ekolojik anlamda öne çıkmıştır. Covid-19 sürecinde çoğu kentte uygulanan 'kilitlen' yaklaşımı ile yerel ekonomiyle kendi kendine yetiyor olmanın ekonomik sürdürülebilirlik anlamında önem taşıdığı gözlemlenmiştir. Sınıflar arası eşitlik, her bireye yaşayabileceği bir konut sağlanması, devazantajlı gruplara verilecek destekler gibi konular toplumsal eşitliğin kamu sağlığı için gerekliliğini vurgulamıştır (Türkoğlu, 2020).

Covid-19 salgınının yarattığı çevresel, ekonomik, kültürel ve sosyo-ekonomik etkiler üzerine yapılan çalışmalar salgının etkilediği noktalara ışık tutmaya çalışmaktadır. Kentlerdeki yüksek nüfus yoğunluğu ve ekonomik faaliyetlerin Covid-19 salgını üzerinde oldukça etkili olduğu düşünülmektedir. Yapılan çalışmalar bu salgının kentler üzerindeki etkilerinin temel olarak; çevresel kalite, sosyoekonomik etkiler, yönetim, yönetişim, ulaşım ve kentsel 
tasarımla ilgili olduğunu göstermektedir. Bu başlıklar içinden çevresel özellikler, hava kalitesi ve su kalitesi gibi çevresel parametreleri içeren çevresel kalite başlı̆̆ı diğerlerine göre daha baskın olmaktadır. Özellikle kentlerdeki karantina dönemlerinde yaşanan hava ve su kalitesindeki değişimler, insan kaynaklı olan faaliyetlerin çevresel etkilerdeki rolünü açıklamaktadır. Böylelikle çevre dostu kalkınma yollarını benimsemek gerektiği ve salgın sonrası dönem için daha adil, dayanıklı ve sürdürülebilir kentler yaratmaya yönelik dönüştürücü adımlar atılması gerektiği savunulmaktadır (Sharifi ve Khavarian-Garmsir, 2020). Henüz sonuçları tam olarak görülmese de geçmiş salgınlar incelendiğinde yaşanan Covid-19 salgınının ilerleyen süreçlerde politik ve yönetimsel etkilerinin de ortaya çıkacağ 1 düşünülmektedir.

Yaşanan salgın sürecinde kentlerde mekansal kullanımlar açısından bazı endişeler yaşanmasıyla beraber farkındalıklar artmaya başlamıştır. Covid-19 ile mücadele sürecinde kentlerdeki eşitsizliğin ortadan kaldırılması düşüncesi oldukça önemli bir durum olmuştur. Kentlerdeki barınma sorunları ve sosyal mesafe kurallarının herkes için aynı derecede uygulanamıyor olması öncelikle çözülmesi gereken bir sorun haline gelmiştir. Hindistan'daki Mumbai kenti gibi gelişmekte olan kentlerde yaşayan 1 milyardan fazla insan gecekondularda ve gayri resmi yerleşimlerde yaşadığı için fiziksel uzaklaşma durumu neredeyse imkansiz hale gelmektedir (Du vd., 2020). Kentlerde yaşam kalitesini artırmak için Covid-19 sonrası kaliteli, güvenli konut ve konut çevrelerinin varlığı, yaya olarak pek çok hizmetlere yüksek düzeyde erişilebilirlik, yürüme mesafesinde yeşil alan ve açık alanların varlığı, sağlık sisteminin ve diğer sosyal hizmetlerin güçlendirilmesi, güçlü, bilinçli toplum ve sosyal ilişkilerin varlığı gibi pek çok konu ön plana çıkmıştır (Türkoğlu, 2020).

Türkiye'de Covid-19 salgınıla beraber özellikle yarı kamusal alanlara sahip çok katlı konutların bahçe kullanımlarının arttığı gözlenmektedir. Sokağa çıkma yasağı olmayan günlerde farklı yaş grupları, günün çoğu zamanını konut yakın çevresinde ve bina adalarının yeşil ve açık alanlarında geçirmektedirler. Bu kapsamda Türkiye özelinde hızlı biçimde devam eden kentsel dönüşüm uygulamaları sonrasında oluşan kentsel doku içerisindeki bu kentsel boşlukların salgın süresinceki kullanımı da göz önüne alınarak yeniden ele alınması gerekmektedir (Atanur, 2020). Ayrıca Türkiye'de salgının kontrol altına alınma sürecinde bina veya mahallelerin karantinaya alınması, daha güvenli toplu taşıma sistemlerinin sağlanması, evsiz kişiler için konaklama imkanların yaratılması, atıkların sık toplanması, yeterli temiz su temini ile park ve kamusal alanlara getirilen kullanım kısıtlamaları şeklinde kararlar alınmıştır (Ahsan, 2020). 
Küresel salgin süresinde kentlerde süregelen kültürel hayatla ilgili değişimler de yaşanmıştır. Kültür-sanat bu süreçte birleştirici ve iyileştirici güçlerden biri olmuştur. Salgın süresince, kültürel alanın desteklenmesi ve canlılığın sürdürülebilmesi adına dünyanın pek çok ülkesinde yerel yönetimler farklı destek yöntemleri benimsemiştir (İstanbul Kültür Sanat Vakfı, 2020).

Covid-19 salgını ile değişen kamusal mekan kullanımlarıyla birlikte virüsün yarattı̆̆ güvensiz ortam yeni hayat düzenini oluşturmaktadır. Böylesi bir güven sorunu yaşanırken, hem kurumlar hem de bireyler uzaktan, temassız ve daha hijyenik bir biçimde yaşama ve iş yapabilme sorunu ile karşı karşıya kalmıştır. Bu bağlamda yerel yönetimler, bu ihtiyaca yönelik olarak pandemi ve sonrası süreçte toplumsal yaşamın bu yönüyle işleyebileceği bir kent ortamını temin eden bir misyon üstenmek durumunda kalmıştır. Bu yönüyle akıllı kent, blokzincir gibi pek çok yaklaşımın yeni düzene uyum göstermede önemli katkılar sağlayacak çözümler sunacağı düşünülmektedir (Polat, 2020).

\section{Kamu Sağlığı ve Akıllı Kent}

Dünya Sağlık Örgütünün tanımılla sağlık; yalnızca hastalığın olmaması durumu değil, tam bir fiziksel, zihinsel ve sosyal iyilik halini ifade etmektedir (WHO, 1946). Sağlıklı kent kavramına yönelik çalışmalar Dünya Sağlık Örgütü'nün 1986 yılında başlattı̆ı ‘Sağlıklı Kentler Programı' ile uygulanmaya başlamıştır. Bu program dünyanın pek çok ülkesinde artan nüfusun kentsel ortamlara taşınması ile kent planlaması ve halk sağlığı arasındaki bağlantının kurulamaması sorununa bir araç olarak sunulmuştur (De Leeuw, 2001). Sağlıklı bir kentsel ortamda yaşamın sürdürülebilmesi için sağlıklı çevresel faktörler gerekmektedir. WHO (1997) sağlıklı bir kentin sahip olması gereken etmenleri 11 başlık altında sıralamaktadır:

- Yüksek kalitede temiz, güvenli fiziksel ortam,

- İstikrarlı ve uzun vadede sürdürülebilir olan bir ekosistem,

- Güçlü, karşılıklı destekleyici bir toplum düzeni,

- Kamuoyunun yüksek düzeyde katılımı ve kontrolü,

- Temel ihtiyaçların karşılanması, (yiyecek, barınma, gelir, iş, güvenlik gibi)

- Kaynak ve deneyimlere erişim ve iletişim,

- Farklı, canlı ve yenilikçi bir şehir ekonomisi,

- Kültürel geçmişle ilişkilendirilmiş bir kent formu,

- Tarihsel mirası koruyan bir kent,

- Herkes için erişilebilir, halk sağlığı, tedavi ve sağlık sistemine erişim,

- Yüksek düzeyde sağlık ve az sayıda hastalık. 
Dünya Sağlık Örgütü’nün ‘Uygulamalı Sağlıklı Kent Planlaması Avrupa Şehirleri Deneyimleri Raporunda" sağlıklı kent planlarında, esenlik ve kullanıcıların yaşam kalitesinin geliştirmeye çalışılması konularında farklı kentler özelinde çok yönlü araştırmaları bulunmaktadır. Kentlerde insan sağlığını korumak ve planlama açısından sahip olunması beklenen hedefleri 12 maddede özetlemektedir (Barton vd., 2010). Bunlar:

- Sağliklı egzersiz,

- Sosyal uyum,

- Barınma kalitesi,

- İstihdam olanaklarına erişim,

- Sosyal ve piyasa imkanlarına erişim,

- Yerel düşük-etkili gıda üretimi ve dağıtımı,

- Toplum ve yol güvenliği,

- Eşitlik sağlanması ve yoksulluğun azaltılması,

- Temiz hava kalitesi ve aşırı gürültünün önlenmesi,

- Temiz su ve sağlık önlemleri,

- Toprak ve çevrenin korunması, temizliği

- İklim dengesinin korunmasıdır. İnsanların yaşadığı fiziksel ve sosyal çevreleri ile yaşam biçimleri, sağlığın başlıca belirleyici unsurlarıdır. Dolayısıyla kentler, içinde yaşayanlarının sağlık koşullarını iyileştirmede özel bir potansiyele sahip olmaktadır. Bu bağlamda yerel yönetimlerin önemli görevlerinden biri de kentsel yaşamın tüm gereksinimlerini düşünerek kamu sağlı̆̆ı politikaları geliştirmektir (Başaran, 2007). Geleceğin kentleri olarak tanımlanarak farklı firsatlar sunan akıllı kent ve ekolojik kent uygulamaları sürdürülebilir planlama ve tasarım ilkeleri çerçevesinde temel ve ortak nitelikleri bünyesinde barındırmanın yanında kendilerine özgü farklı odak noktaları olan yaklaşımları ifade etmektedir (Gülersoy, 2011).

\section{Akıllı Kent Kavramı ve Gelişimi}

'Akıllı' kelimesine alternatif olarak 'dijital veya zeki' sıfatlarıyla da kavramsal olarak çeşitlenebilen akıllı kentlerin pek çok tanımı mevcuttur. Akıllı kenti çerçevelemek için onun her boyutuna vurgu yapan tek bir tanım mevcut değildir. Akıllı kent yaklaşımı kökenlerini 1990'ların sonlarında alternatif bir büyüme yaklaşımı olarak tarif edilen akıllı büyüme yaklaşımından almaktadır (Basiri, 2017). 19.yüzyılın sonlarında başlayan bu yaklaşım ile kentlerin refahını destekleyen küresel ve bilgilendirici kent (1980), kent markalaşması (1990), kültürlerarası kentler (1996) ile 
akıllı kent ve muhteşem kent (2000) şeklinde çeşitli paradigmalar ortaya koyulmuştur (Abusaada ve Elshater, 2020).

Akıllı kentlerin gelişimine katkı sağlayan; "akıllı vatandaş, akıllı yönetişim, akıllı ekonomi, akıllı hareketlilik, akıllı çevre ve akıllı yaşam" gibi altı temel unsur bulunmaktadır (Giffinger, 2007). Bu başlıklar içinden doğal kaynaklarla ilişkili olan akıllı çevre ve yaşam kalitesini içeren akıllı yaşam başlıkları, kentleri sağlıklaştırma ve kamu sağlığı yönünden birtakım önerilerde bulunmaktadır.

Tablo 1. Akıllı kentin ana ve alt bileşenleri (Giffinger, 2007).

\begin{tabular}{ll}
\hline Akıllı Ekonomi (Rekabet) & Akıllı Vatandaş (Sosyal ve Beşeri Sermaye) \\
\hline Yenilikçi ruh & Yeterlilik seviyesi \\
Girişimcilik & Yaşam boyu öğrenmeye yakınlık \\
Ekonomik imaj ve ticari markalar & Sosyal ve etnik çoğulluk \\
Verimlilik & Esneklik \\
İş gücü piyasasının esnekliği & Yaratıcılık \\
Uluslararası yerleşiklik & Kosmopolitlik, açık fikirlilik \\
Dönüştürme yeteneği & Kamusal hayata katılım \\
\hline Akıllı Yönetişim (Katılım) & Akıllı Hareketlilik (Ulaşım ve ICT) \\
\hline Karar verme sürecine katılım & Yerel erişilebilirlik \\
Kamu ve sosyal hizmetler & Uluslararası erişilebilirlik \\
Şeffaf yönetim & ICT altyapısının kullanılabilirliği \\
Siyasi stratejiler ve perspektifler & Sürdürülebilir, yenilikçi ve güvenli ulaşım \\
\hline Akıllı Çevre (Doğal Kaynaklar) & Akıllı Yaşam (Yaşam Kalitesi) \\
\hline Doğal koşulların çekiciliği & Kültürel tesisler, sağlık koşulları \\
Kirlilik & Bireysel güvenlik, konut kalitesi \\
Çevresel koruma & Eğitim tesisleri, turistik çekicilik \\
Sürdürülebilir kaynak yönetimi & Sosyal uyum \\
\hline
\end{tabular}

Akıllı bir kent, refah, sürdürülebilirlik, dayanıklılık, acil durum yönetimi veya etkili ve adil hizmet sunumu açısından daha iyi karar almaya rehberlik edebilir (Un Habitat, 2016). Kentlerde yaşanabilecek olan sonraki salgınlar ve bulaşıcı hastalıklar için mevcut kentlerin salginla yüzleşmelerinde teknoloji destekli son gelişmeleri ve akıllı kent paradigmasının evrimi ile yenilikçi yaklaşımları gündemdedir. Bu anlamda umut verici kalkınma senaryoları, iyi uygulamalar ve potansiyelleri ile olası bulaşı ı hastalıklar karşısında kentlerdeki acil durumların nasıl yönetileceği tartı̧ılmaktadır (Costa, 2020).

\section{Akıllı Kent ve Salgın Yönetimi}

Akıllı kent, veri ve dijital teknolojiyi kentlerin yaşam kalitesini artırma hedefiyle kullanmaktadır. Veri bilimi ve mekansal görselleştirmenin kullanılmasıyla başlayan kentlerin akıllı hale gelmesinin kökeni 1854 yllında Dr. John. Snow'un yap- 
tığı çalışmayla yakından ilişkilidir. Snow, 1850'lerde hava kirliliği kaynaklı olduğuna inanılan kolera salgını sonucu ölen kişilerin adreslerini bir harita üzerinde her ölümü bir siyah çizgi ile belirterek hanedeki ölüm sayısına göre bir çizim gerçekleştirmiştir. Haritaya su kaynakları gibi ek katmanlar da ekleyerek kolera vakalarının Londra'daki yayılışını görselleştirmiştir. Bu öncü veri görselleştirme ile yaşanan yere su sağlayan pompoya en yakın olan yerleşimlerdeki ölüm oranlarının daha fazla olduğu, kolera virüsünün daha önce varsayıldığı gibi hava yolu ile değil su kaynakları yoluyla yayıldığı keşfedilmiştir. Bu yöntem ile çözüm yolunun, verilerin toplanıp görselleştirmesiyle bulunacağına odaklanan bu harita modeli teknik olarak ilk akıllı kent örneği olmaktadır (Corburn, 2019; Öztaş, 2020; Özüduru 2020).

Akıllı kent uygulamaları yüz yüze etkileşim ve teması önleyerek fiziksel uzaklaşmayı sürdüren teknolojiler sunmaktadır. Bu anlamda kullanılan teknoloji, enfekte insanların yerinin tespitini kolaylaştırmaktadır. Drone ve robot teknolojisi, tıbbi personel olarak çalışarak temel hizmetler için yararlı olmaktadır. Herhangi bir fiziksel temas olmadan, gıda, ilaç gibi temel ihtiyaçlarının sunulması için kullanılan akıllı dağıtım sistemlerinin temassız teknolojilerden biri olduğu gözlemlenmiştir (Jaiswal vd., 2020).

Akıllı kentlerde yaşanan pandemi sürecini hafifletmek adına yaygin olarak uygulanan ve bu olasılıklar içinde gelecek vaat eden çözümler; otomatikleştirilmiş hastaneler ve sağlık hizmetleri sistemleri, akıllı ulaşım, salgin tespiti sonrası hemen harekete geçen müdahale ekipleri, araştırma ve yenilikler, acil durum tespit edildiğinde insanları uyaran bildirim mesajları olarak beş temel başlıkta sınıflandırılabilir (Costa 2020).

Covid-19 salgını, ülkeler, kentler ve toplumların sağlık, ekonomi ve kent dokusunu ve değerlerini tehdit edici bir boyuta ulaşmıştır. Bu süreçte Birleşmiş Milletler Konut ve Kentsel Kalkınma Ajansı (UN-Habitat), pandemi; hazırlık, önleme, müdahale ve kurtulmalarına yardıma olmak için ulusal ve yerel yönetimlerle birlikte çalışmıştır. Küresel, bölgesel ve ülke düzeyindeki çalışmalar için kapsamlı programlar hazırlanmıştır. Avrupa Komisyonu, Avrupa İnovasyon Konseyi Covid-19 salgınına tedavi, test, izleme veya diğer yönlerden katkı yapacak teknoloji ve yeniliklere sahip işletmeler için çağrıda bulunmuştur. Bu projeler; MBENT: Salgın hastalıklar sırasında insan hareketliliğinin takibi, EpiShuttle: Özel izolasyon üniteleri, m-TAP: Hava temizleme sistemleri üzerinedir. Bunlardan MBENT gelecekteki akıllı kent projeleri geliştirilirken referans olarak alınabilecek bir projedir (Yilmaz, 2021).

Covid-19 salgını sonrası akıllı kentlerde devlet önderliğinde pek çok teknolojik yaklaşımın hızla toplumsal yaşama entegre edildiği görülmektedir. 
Akıllı kent ünvanı taşıyan Singapur 20 Mart 2020 tarihinde TraceTogether ve SafeEntry sistemi ile salgın sırasında dijital gözetim sunan akıllı uygulama tabanlı izleme programlarına geçmiştir (Das, 2020). Türkiye'de de benzer şekilde Sağlık Bakanlığı tarafından Nisan ayından itibaren yeni tip koronavirüs hakkında bilgilendirme ve yönlendirmeler içeren, salgın hastalıkla ilgili yaşanabilecek sorunları minimuma indirmeyi amaçlayarak geliştirilen bir mobil uygulama olan 'Hayat Eve Sığar' uygulaması kullanılmaktadır.

\section{Akılh Kent Uygulamalarnmn Salgın Yönetimi Açısmdan Değerlendirilmesi}

- Verilerin birleştirilip görselleştirmesiyle oluşturulan haritalama teknikleri, (Corburn, 2019)

- Akıllı kent uygulamalarının yüz yüze etkileşimi minimuma indiren ve fiziksel teması azaltan teknolojiler sunması,

- Sunulan teknolojilerle, enfekte insanların yerinin tespitinin kolaylığını sağlaması,

- Gıda, ilaç gibi temel ihtiyaçlarının sunulması için akıllı dağıtım sistemlerinin temassız kullanımı, (Jaiswal vd., 2020)

- Salgin tespiti sonrası hemen harekete geçen müdahale ekipleri

- Akıllı sağlık hizmetleri sistemleri sunulması,

- Acil durum tespit edildiğinde insanları uyaran bildirim mesajlarının yönlendirilmesi, (Costa, 2020)

- Büyük veri analitiği yoluyla salgınları belirlemek, izlemek ve tahmin etmek,

- Gelişmiş yüz tanıma ve kızılötesi teknolojiler yoluyla kamu güvenliğini artırmak için yapay zeka kullanımı,

- Malzemeleri sterilize etmek, tedarik etmek ve gözetlemeye yardıma olmak için dronlar veya akıllı robotların kullanımı,

- Virüsü incelemeye, virüsü teşhis etmeye ve potansiyel tıbbi tedavileri geliştirmeye yardımcı olacak araçlar,

- İnsanlar arası fiziksel temasın azaldığı dönemlerde sanal iletişimi kolaylaştırmak için akıllı uygulamalar ve yapay zeka destekli sohbet robotlarının kurulması, (Inn, 2020)

- Kent içi farklı ulaşım modlarının bulaşma riskini hesaplayabilen akıllı hareketlilik kısıtlamaları geliştirilebilmesi, (Yılmazsoy vd, 2021)

- Kamu sağlı̆̆ına destek veren, nüfus gözetimi/kontrolü, aktif yaşlanma, sağlıklı yaşam biçimleri sunması, hizmet almakta zorlanan kişilere verilen 
destekler, acil durum müdahaleleri, bakım hizmetleri organizasyonu ve sosyalleşmeyi desteklemek için kullanılabilen akıllı kent uygulamaları, (Rocha $\mathrm{vd}, 2019$ )

- Temel anlamda sağlıkla mücadelede kentlerde "uygun su ve sanitasyon sistemleri ve akıllı evler inşa edilmesi", (Y1lmazsoy vd., 2021)

- Akıllı kentlerde devlet önderliğinde salgın sırasında digital gözetim sunan akıllı uygulama tabanlı izleme programlarının toplumsal yaşama entegre edilebilmesi, (Örnek: Singapur, Mart 2020'de TraceTogether ve SafeEntry uygulamaları)

- Salgın süresince hasta takibinde ve hastalık hakkında insanları bilgilendirme ve yönlendirmeler içeren, hastalıkla ilgili yaşanabilecek sorunları minimuma indirmeyi amaçlayarak geliştirilen mobil uygulamalarının artırılması şeklindedir (Örnek: Türkiye Nisan 2019, Hayat Eve Sığar uygulaması).

\section{Tartışma ve Sonuç}

Akıllı kent 1980'lerden itibaren akıllı büyüme yaklaşımı temelinde gelişim gösteren bir planlama yaklaşımı olarak karşımıza çıkmaktadır. Aslında bahçe kent, ekolojik kent, sürdürülebilir kent, yavaş kent, yeşil başkent gibi pek çok kavramsal yaklaşımın özünde olduğu gibi akıllı kentte de kentlerin sürdürülebilir gelişimi hedeflenmektedir. Akıllı kent, sunduğu bileşenler, araçlar ve uygulamalar ile sürdürülebilir kentleşme açısından kontrollü büyümeyi hedef alan akıllı büyüme temelli bir yaklaşımı ifade etmektedir. Teknolojinin kentsel gelişmeye maksimum derecede entegre edilmesi ile bilgi iletişim teknolojilerinin kullanımını teşvik etmektedir. Dolayısıyla özellikle yaşanan pandemi sürecinde meydana gelen olumsuz durumların engellenmesi noktasında akıllı kent uygulamalarının etkinliğinin tartışılması söz konusu olmaktadir.

Kentlerdeki pek çok mekan kullanımının dönüşümüne neden olan salgınlardan biri olan Covid-19 pandemisi ile gündelik yaşamda insan ve mekan ilişkileri yeniden tanımlanmıştır. Salgın süresince kentlerin bu süreci dirençli şekilde atlatabilmesi adına, hızlı, kolay ve düşük maliyetli stratejiler uygulanıp sürdürülebilir ve esnek tasarımlarla desteklenen kentsel açık alanlar önem kazanmıştır. Çeşitli etkinlikler için dönüştürülebilir geniş rekreatif alanların kullanımının artırılması, kentteki yaya hareketinin sağlıklı şekilde devam ettirilebilmesi için trafik akışının yavaşlatılması gibi çeşitli önlemler düşünülmüştür. Salgın süresince enfekte olan kişileri taşımak için sürücüsüz otonom araçların kullanılması, bulaşma riskini azaltacağından akıllı ulaşım anlamında bir çözüm olmaktadır. Benzer şekilde akıllı kent uygulamalarına 
bakıldığında salgından etkilenen hasta bireylerin teşhisi konusunda akıllı uygulamaların kullanılabildiği görülmektedir. Velibeyoğlu'na (2016) göre yönetişimin de bilgisayar kodları tarafından kontrol edildiği bir dünyada akıllı kentlerin sunduğu vaatlerin ötesinde bir dijital kıyamet senaryosu da gözetilmelidir. Teknolojik denetimin mekansallaşması ile akıllı kentlerin değil duyusal kentlerin ön plana çıktığı yaklaşımların da düşünülmesi gerekmektedir. Dünya Sağlık Örgütü, içinde bulunduğumuz Covid-19 salgını da dahil olarak, 1990 sonrası salgınlar için 'virüs çağı' olarak adlandırdığı bu dönemin (Yılmazsoy vd., 2021) sonlarında kentlerin doğa ve insan üzerinde bıraktı̆̆ı negatif izlerin azaltılması amacıyla daha yaşanılır kentler oluşturabilmek için geliştirilen planlama yaklaşımlarından kompakt kent, sürdürülebilir kent, eko kent, düşük karbon kent, yaşanabilir kent, dijital kent, akıllı kent gibi yaklaşımları, özünde çevre dostu, ekolojik (çevresel ve kültürel) farkındalık yaratarak çevre kalitesini artırma hedefini teknolojik imkanlarla gerçekleştirmeyi amaçlayan yaklaşımlar olarak nitelendirmektedir (Sınmaz, 2013). Dolayısıyla sürdürülebilirlik, kentsel dirençlilik, akıllı kent ve eko-kent gibi kavramlar tartışılmakta iken yaşam döngüsünde eşi benzeri olmayan bir sürecin hakim olduğunu söylemek mümkündür. Kentlerde yaşayanlar kolay olmayan, sürekli evrilen, devingen ve yepyeni bir yaşam ile karşı karşıya kalmaktadır. Dolayısıyla geleceği öngörülemez kılan bu süreç, bilinen kentsel politika ve yönetim şekilleri, şehircilik ilkeleri, planlama esasları ve araçlarını sorgulatır duruma gelmiştir (Özüduru, 2020).

Yaşanan Covid-19 salgını ile değişen yaşamda konut dışında gerçekleştirilen etkinliklerin pek çoğunun bu alana taşınması, insanlarla ortak geçirilen zamanların kısitlanması, etkinliklerin ertelenmesi gibi salgindan korunma amaçlı mekan kullanım biçimleri değişmiştir. Gündelik yaşamdaki bu dönüşümler mekanların kullanım süresi ve yoğunluklarını da etkilemiştir. Özellikle kamusal alanların kentteki kullanımları tekrar düşünülmeye başlanmış, erişilebilirlik, yeşil dokunun sürekliliği ve kentsel mekanın bina sınırlarıyla oluşan bir boşluktan ziyade planlanarak tasarlanmış bir biçimde olması gibi konular önem kazanmıştır. Biçimlerin ya da yapıların kendi biçimlenişlerinin ve kentteki sürdürülebilirliklerinin önemi kadar yapıların üzerine yerleştirildiği ve yapılar tarafından tanımlanan zeminler ya da boş alanlar, en az bu biçimlerin ya da yapıların kendileri kadar önemli ve anlamlı olmalıdır. Salgınla beraber kentlerdeki mevcut sağlık tesislerinin esnek tasarıma uygun olup olmayışı, bulundukları konumları da yine salgınla beraber tartışılan konulardan biri olmuştur. 
Covid-19 krizi, dünya çapında ekonomik, sosyal ve çevresel etkileşimlerin birbirleriyle olan güçlü bağını bir kere daha ortaya koymuştur. Doğal kaynakları korumanın önemi, sistemlerin gelişebilecek tehdit ve streslere karşı dayanıklılık durumu, yeni düzenlere karşı sağlanabilecek uyum düzeyi gibi gerçeklerle karşı karşıya kalınmıştır. Dolayısıyla gerekecek önlemlerin alınmasıyla gelecekteki oluşabilecek tehditlere hazırlı olabilmek adına toplum direncinin artırılması gerekmektedir (Karaer, 2020). Sağlıklı bir topluluk oluşturulması için, bölgelere ayırmada, tasarımlarda ve diğer gerekli iyileştirmelerde halk sağlığı konularını vurgulayarak hazırlık yapmak için kapsamlı toplum planlamasına ihtiyaç duyulacaktır. Bu açıdan kentsel tasarım, kentsel planlama ve yönetimde akıllı teknolojiler ve afet müdahale yaklaşımlarının entegrasyonuna ihtiyaç vardır (Ahsan, 2020).

Çalışma kapsamında akıllı kentin kuramsal kısımda bahsedilen altı göstergesinden özellikle 'Akıllı Yaşam ve Akıllı Çevre' başlıklarının içeriklerinin salgın süresince detaylıca düşünülmesi gerekmektedir. Yaşamın akıllı hale gelmesini sağlama amacı güden akıllı yaşam başlığında bahsedilen kentteki sağlık koşullarının iyileştirilmesi, konut kalitesi, herkes için hizmetlere erişimde eşitlik sağlanması gibi başlıkların doğrudan salgın ve kent ilişkisi çerçevesinde değerlendirmesi yapılabilir. Benzer şekilde kentteki doğal kaynakların kullanımı ile akıllı çevre yaratılması başlığında da çevrenin korunması, kentlerdeki kirliliğin azaltılması, sürdürülebilir kaynakların kullanımı gibi tanımlamaların içeriklerinde de özellikle kentsel mekanda temizlik ve salgın ilişkisi kurulabilir.

Sonuç olarak sürekli gelişen teknolojik araçların da sayesinde pek çok kentte benimsenen akıllı kent yaklaşımının özellikle kamu sağlığı noktasında, kentteki sürdürülebilirliği artıracak şekilde tekrar düşünülmesi gerekmektedir. Yaşanan pandemi süreci ayrıca kamusal mekanların bireylerin kullanımı açısından önemini açıkça ortaya koymaktadır. Kentlerin akıllı olma noktasında pek çok sisteme entegre edilen teknolojik gelişmelerin yanında, aslında bu sürecin insanın doğaya olan ihtiyacının ne denli fazla olduğunu ve kentsel açık alan kullanımların fiziksel temas bağlamında tekrar düşünülerek uygun boyutlandırmalarının yapılmasını da gerekli kılmaktadır. 


\section{Extended Abstract}

\section{The City and the Pandemic: An Evaluation on New Approaches and Public Health}

\author{
Ece Varol \\ ORCID: 0000-0002-2502-6448
}

\author{
Ahmet Melih Öksüz \\ ORCID: 0000-0002-9312-7312
}

With the Covid-19 pandemic that emerged towards the end of 2019, the virus spread to different cities of the world at a very fast pace. The disease created by this virus was declared a global pandemic by the World Health Organization on March 11, 2020. An important point that distinguishes this pandemic from other pandemics in the historical process is that not all people who get sick experience the disease process in a similar way. Therefore, people who survive the disease without experiencing any symptoms are in a carrier state by other members of the society. For this reason, one of the first measures taken was the quarantine application. Along with the quarantine, curfews were also introduced. With these prohibitions, the contact of people has decreased considerably. In this way, it was tried to prevent the spread of the disease in the community. In addition to the measures taken to prevent the rapidly increasing spread of the Covid-19 virus in the society, restrictions have been imposed on the use of public spaces. There have been radical changes in the use of curfews and closed spaces. The purpose of this is to limit the contact between people at the best level against this virus, whose spread cannot be prevented. There have been changes in social life such as shopping for groceries at certain times of the day or only on weekends, and limiting users in closed areas. Therefore, the squares of many cities, which are in our minds with the crowd of people, have become desolate.

One of the primary goals of urban planning is to make cities healthier. Creating healthy environments by establishing a good balance between people and nature in limited land use is indispensable for a healthy life. The healthy urban movement, which is one of the planning movements of the 19th century, is a movement that 
emphasizes the importance of the necessary arrangements for improving the health conditions in the cities. Movements such as the Garden City and the Beautiful City, known in the urban planning literature, were developed for the purpose of creating a healthy city. These movements have principles that pay attention to social equality among people, by keeping the building density at certain levels, making green and public spaces easier to access urban services. Housing of people in healthy housing structures and providing personal hygiene conditions affect not only their own health but also the health of the whole society. Today, with the globalization, the difference in life between individuals is increasing day by day. This further clarifies the distinction between healthy and unhealthy environments. Regulations to be made in this aspect require that everyone in urban environments have the right to a fair life and offer equality in access to urban services. Approaches such as eco-city, smart city, digital city and sustainable city create awareness to reduce the destruction caused by people on cities and to construct sustainable urban environments. Especially in this age of unpredictable virus, while being integrated into a new life order, current urban policies, administrations, urban planning principles, principles and functioning of tools are questioned.

An important point for the current Covid-19 pandemic and other pandemics that may occur in the future is to know the precautions to be taken in case of an pandemic. While trying to reduce the spread of the virus, it is important to inform the community and follow the process within the predetermined rules. In this sense, responsibilities fall to urban administrations and authorities. With the help of technological developments, it is possible to maintain urban health services, especially by minimizing physical contact. The changes in the public space, especially with the Covid-19 pandemic, prove the importance of the solutions offered by the planning approaches to the city during the pandemic. The fact that the quality of urban life does not decrease during and after the pandemic is possible with the development of smart interventions to be made during the pandemic.

The main purpose of the preparation of this study is to emphasize the changes caused by the Covid-19 pandemic on social life and cities. Along with the changes experienced, the solutions and effects of current urban planning and design approaches against the effects of the pandemic are focused. Considering that this process, which significantly changed human life, also affected urban life, public space uses were the places most affected by this process. Within the scope of the study, the evaluation of the Covid-19 pandemic in relation to the literature is presented. Especially with the experiences gained from the past pandemics, it is questioned what new approaches this Covid-19 pandemic brings with it in the changes in the use of public spaces. Examining the application areas of discourses such as smart 
city in the context of the pandemic also contributes to the results section of the study. The results of this study contribute to the literature in terms of evaluating new approaches in the use of pandemic and public space and discussing the effects of discourses such as smart city on this process. With this aspect, the study is expected to be a source of inspiration for future studies.

The findings obtained as a result of the study are that the smart city approach, which is supported in many cities in the world together with the developing technological tools, can support sustainable development. During the Covid-19 pandemic, the importance and place of public spaces in human life has once again emerged. Concepts such as health regulations in housing and urban spaces, the free use of urban spaces in collective activities, the qualities of urban open spaces and walkability in urban spaces have come to the fore. In this respect, it is clear that smart cities, which is one of the urban planning approaches, will support the pandemic in many ways technologically. However, especially during the pandemic, it will be necessary to reconsider the use of public spaces in the context of physical contact and to re-evaluate their sizing in this context.

\section{Kaynakça/References}

Abusaada, H. ve Elshater, A. (2020). Covid-19 challenge, information technologies and smart cities: Considerations for well-Being. International Journal of Community WellBeing, 3(3), 417-424.

Ahsan, M. M. (2020). Strategic decisions on urban built environment to pandemics in Turkey: Lessons from covid-19. Journal of Urban Management, 9(3), 281-285.

Aslan, R. (2020). Tarihten günümüze epidemiler, pandemiler ve covid-19,. Ayrıntı Dergisi, 8(85), 34-41.

Atanur, G. S. (2020). Covid-19 ve neden evinizin yanındaki bahçeye ihtiyacınız var?, ", 29 Mayıs 2021 tarihinde http://www.skb.gov.tr/ adresinden erişildi.

Banai, R. (2020). Pandemic and the planning of resilient cities and regions. Cities, 106, 1-6.

Barton, H., Mitcham, C., Tsourou, C. (2010). Uygulamalı sağlıklı kent planlaması

Avrupa şehirleri deneyimleri. Who Sağhlkh Kent Planlaması Şehir Faaliyet Grubu Raporu, Who Avrupa Bölge Ofisi.

Başaran, İ. (2007). Sağlıklı kentler kavramının gelişiminde sağlıklı kentler projesi. Dokuz Eylül Üniversitesi Sosyal Bilimler Dergisi, 9(3), 208.

Bayhan, V. (2020). Covid-19 küresel salgın bağlamında gündelik hayatın denetimi. Şehir Araştırmalarn Dergisi, 6(12), 37-50.

Carmona, M., Heath, T., Tiesdell, S. ve Oc, T. (2010). Public Places, Urban Spaces: The Dimensions of Urban Design, 2nd Edition, New York: Routledge.

Corburn, J. (2019). Sağhlklı şehir planlamast-mahalleden ülkeye sağllkta eşitlik, İstanbul: İnsev Yayinları. 
Costa, D. G. ve Peixoto, J. P. J. (2020). Covid-19 pandemic: A review of smart initiatives to face new outbreaks. IET Smart Cities, 2, (2), 64-73.

Çetintahra, G. E. ve Çubukçu, E. (2015). Ebeveynlerin fiziksel çevreye yönelik algısının çocukların fiziksel aktivite düzeylerine etkisi. Planlama Dergisi, 25(3), 205-211.

Das, D. ve Zhang, J. J. (2020). Pandemic in a smart city: Singapore's covid- 19 management through technology and society. Urban Geography, 42 (3),1-9.

De Leeuw, E. (2001). Global and local (glocal) health: The Who healthy cities programme. Global Change and Human Health, 2(1), 34-45.

Du, J., King, R. ve Chanchani R. (2020). Tackling inequality in cities is essential for fighting covid-19. 28.10.2020 tarihinde https://www.wri.org/blog/2020/04/coronavirus-inequality-cities adresinden erişildi.

Erdönmez, M. E. ve Akı, A. (2005). Açı kamusal kent mekanlarının toplum ilişkilerindeki etkileri. Megaron, 1(1), 67-87.

Giffinger, R. ve Pichler-Milanović, N. (2007). Smart cities: Ranking of European medium-sized cities. Viyana: Centre of Regional Science.

Gülersoy, N.Z. (2011). Bölüm 3: Şehirleşme: Akıllı şehir. Vizyon 2050 Türkiye Raporu (ss 3946). İstanbul: TÜSİAD

Karabaş, B. (2008). Sosyal sinıflarm şekillendirdiği kent: Londra. 31.05 .2021 tarihinde https://v3.arkitera.com/h25937-sosyal-siniflarin-\%C5\%9Eekillendirdigi-kentlondra.html adresinden erişildi.

Karaer, F. (2020). Covid-19 sonrası çevre sorunlan ve ortaya çıkan çevre anlayışı, 29 Mayıs 2021 tarihinde http://www.skb.gov.tr/ adresinden erişildi.

İstanbul Kültür Sanat Vakfı. (2020). Covid-19 salgını karşısında kentlerde kültürel hayat. Çözüm Üreten Kentler 002 (ss 28-33). İstanbul: Marmara Belediyeler Birliği

Inn, T. L. (2020). Smart city technologies take on covid-19. Penang Institute Issues, 110.

Jaiswal, R., Agarwal, A. ve Negi, R. (2020). Smart solution for reducing the covid-19 risk using smart city technology. IET Smart Cities, 2(2), 82-88.

Oxford İngilizce Sözlüğü. (2020). 03 Ekim 2020 tarihinde https://dictionary.cambridge.org/tr/s\%C3\%B6zl\%C3\%BCk/ingilizce/pandemic adresinden erişildi.

Özden, K., ve Özmat, M., (2014). Salgın ve kent: 1347 veba salgınının Avrupa'da sosyal, politik ve ekonomik sonuçları. İdealkent, 5(12), 60-87.

Öztaş, Ç. Ç. (2020). Kentlerin "akullanması"na pandemi etkisi. 29 Ekim 2020 tarihinde https://wrisehirler.org/haberler/kentlerin \%E2\%80\%9Cak\%C4\%B1llanmas\%C4\%B1\%E2\%80\%9Dna-pandemi-etkisi adresinden erişildi.

Özüduru, H. (2020). Covid-19 ve şehirler. İdealkent Yayınlarn: Ankara

Sharifi, A. ve Khavarian-Garmsir, A. R. (2020). The covid-19 pandemic: Impacts on cities and major lessons for urban planning, design and management. Science of The Total Environment, 749, 1-14. 
Tekeli, İ. (2020). Salgınlar ve kentler sarmalında dünyanın geldiği nokta: Covid-19. Ö,F. Ç. (Der.), Salgın ekonomisi (ss. 53-88). Ankara: Efil Yayınevi Yayınları.

Temel, M.K ve Ertin, H. (2020). 1918 Grip pandemisi kıssasından covid-19 pandemisine hisseler. Anadolu Kliniği Tıp Bilimleri Dergisi, 25 (1), 63-78.

Türkiye Bilimler Akademisi. (2020). Covid-19 pandemi değerlendirme raporu. Türkiye Bilimler Akademisi Yaymlar, 5 Ekim 2020 tarihinde http://www.tuba.gov.tr/files/yayinlar/raporlar/Covid-19\%20Raporu-revize.pdf adresinden erişildi.

Türkoğlu, H. (2020). Covid-19 sonrası kent ve kent planlama, 10 Kasım 2020 tarihinde http://www.skb.gov.tr/ adresinden erişildi.

TMMOB Şehir Plancıları Odası. (2020). Halk Sağlığı Aynı Zamanda Toplumsal Mekân ve Kamusal Planlama Sorunsalıdır, 25 Ekim 2020

tarihinde http://www.tmmob.org.tr/icerik/spo-halk-sagligi-aynizamanda toplumsalmekan-ve-kamucu-planlama-sorunsalidir adresinden erişildi.

Parıldar, H. (2020). Tarihte bulaşıı hastalık salgınları. Tepecik Ĕ̆itim ve Araştırma Hastanesi Dergisi, 30, (Ek Say1), 19-26.

Polat, İ. H. (2020). Covid-19, blokzincir ve akıllı şehirler. Çözüm Üreten Kentler 002, (ss 7981). İstanbul: Marmara Belediyeler Birliği

Rocha, P. N., Dias, A., Santinha, G., Rodrigues, M., Queirós, A., ve Rodrigues, C. (2019). Smart cities and healthcare: A systematic review. Technologies, 7(3), 58.

Sınmaz, S. (2013). Yeni gelişen planlama yaklaşımları çerçevesinde akıllı yerleşme kavramı ve temel ilkeleri. Megaron, 8(2), 76.

UN-Habitat (2016). World cities report: Urbanization and development. 20 Kasım 2020 tarihinde https://unhabitat.org/sites/default/files/downloadmanager-files/WCR- 2016-WEB.pdf adresinden erişildi.

Velibeyoğlu, K. (2016). Akıllı kentler: vaatler ve ötesi. Yenilikçi Sürdürülebilir Gelişme Stratejileri Bă̆lamında Türkiye Ekonomisinin Geleceğine Yönelik Çözüm Arayısları, (ss 1-13). İzmir: Dokuz Eylül Üniversitesi

Yılmaz, B. (2021). Pandemi odaklı "proaktif akıllı şehirler". 27 Mayıs 2021 tarihinde http://www.skb.gov.tr/ adresinden erişildi.

Yılmazsoy, B. K., Aydemir, K. KP ve Akdemir, Ç.(2021). Tarihi süreçte salgın hastalıklar ve değişim: Covid-19 sonrası mimari ve kent. Journal of Social and Humanities Sciences Research. 8,(66), 425-440.

Word Health Organization (WHO).(1946). 20 Ekim $2020 \quad$ tarihinde https://www.who.int/about/governance/constitution adresinden erişildi.

Word Health Organization (WHO). (1997). The World healt report, 25 Ekim 2020 tarihinde https://www.who.int/whr/1997/en/whr97_en.pdf adresinden erişildi. 